\title{
Selected Issues In Strategic Planning of Public Sector In Indonesia
}

\author{
Fajar Eko Antono ${ }^{1}$ and Keziah Cahya Virdayanti ${ }^{2}$ \\ Ministry of Public Works and People's Housing of Republic Indonesia
}

\begin{abstract}
Development planning is one of the important functions of government in the implementation of the state administration. Progress of a country depends on the quality of its development planning implemented by government agencies (public sector), which will determine the success of achieving national development goals. The problems of development planning are inherently in the development planning system itself. There are still some weaknesses in strategic planning in the public sector such as: planning as a legal-formal process; errors in goal setting; difficulty in predicting the future; less strategic participatory planning processes; difficulties in formulating systematic, tiered performance indicators; difficulties in measuring the impact and benefit performance; and difficulties in prioritization in programming and budgeting. There are short-term problems that are difficult to overcome, but for some other problems can be made to overcome them by adding refinements to existing mechanisms as well as adding new mechanisms in strategic planning practice.
\end{abstract}

Keywords: strategic planning; the public sector; performance indicators; participation; priority. 
Beberapa Permasalahan Dalam Perencanaan Strategis Sektor Publik Di Indonesia

Fajar Eko Antono dan Keziah Cahya Virdayanti

KEMENTERIAN PEKERJAAN UMUM DAN PERUMAHAN RAKYAT (PUPR)

\section{Latar Belakang}

Beberapa waktu yang lalu, pada tanggal 25 April 2017, Presiden Joko Widodo membuka Musrenbang Nasional 2017 dengan pidato yang cukup menarik perhatian, khususnya bagi para pemerhati dan pelaku perencanaan pembangunan. Pasalnya, beliau berpendapat bahwa perencanaan pembangunan saat ini masih belum fokus dan belum memiliki prioritas yang jelas. Penganggaran APBN dan APBD hanya dianggap sebagai sebuah rutinitas tanpa ada terobosan baru (sumber: www.cnnindonesia.com). Kegelisahan Bapak Presiden ini memang cukup beralasan. Secara logika, memperlakukan proses perencanaan sebagai sebuah rutinitas dapat berakibat fatal, apalagi dalam skala sebesar negara. Tidak peduli seberapa kuat opini publik untuk meminta perubahan, semua usaha itu tidak akan menghasilkan dampak yang signifikan, jika proses perencanaannya sendiri tidak didesain untuk mendorong terobosan.

Namun, apabila kita menilik lebih jauh, apa yang disampaikan oleh Bapak Presiden ini sebenarnya memang merupakan salah satu permasalahan yang kerap menghambat efektivitas sistem perencanaan yang kita adopsi selama ini. Secara filosofis dan konseptual, sistem perencanaan pembangunan yang kita adopsi sampai dengan saat ini sangat kuat dipengaruhi oleh konsep "strategic planning", sebuah sistem perencanaan yang booming pada tahun 1970'an. Sebagai salah satu tipe pembentukan strategi, strategic planning atau perencanaan strategis dapat didefinisikan sebagai perencanaan yang dicapai dengan cara-cara yang terstruktur dan formal (Mintzberg, 1998). Dalam hal ini, strategi dibentuk oleh fungsi perencanaan tertinggi dalam struktur organisasi, sementara unit-unit dibawahnya hanya melakukan implementasi. Strategi yang dihasilkan melalui proses ini dijabarkan secara eksplisit dan detail, dengan harapan agar pelaksanaannya dapat dilakukan dengan kesesuaian tertinggi terhadap rencana. Asumsi dasar dari sistem perencanaan strategis ini adalah ibarat cara kerja sebuah mesin: apabila setiap bagian dari mesin tersebut dibuat secara spesifik dan disusun sesuai dengan blueprint, maka otomatis mesin akan bekerja dengan baik dan menghasilkan keluaran yang diinginkan.

Menurut Mintzberg dalam bukunya Strategy Safari, proses perencanaan strategis terdiri dari 5 (lima) tahap. Pertama, penyusunan dan penjabaran tujuan sehingga menghasilkan rumusan yang terukur secara kuantitatif, yang merupakan konsekuensi dari pendekatan perencanaan strategis yang formal. Kedua, audit faktor eksternal dan internal, yang merupakan pengembangan dari metode analisis Strength Weakness Opportunity Threat (SWOT). Salah satu ciri khas perencanaan strategis tertuang dalam tahap ini, yaitu memprediksikan skenario di masa depan. Ketiga, melakukan evaluasi terhadap strategi yang sudah terbentuk. Dalam konteks bisnis atau sektor privat, evaluasi ini sebagian besar diarahkan kepada analisis finansial, sedangkan dalam konteks sektor publik, evaluasi tersebut seharusnya diarahkan kepada analisis ekonomi atau kemanfaatan sosial (social benefit). Keempat, perencanaan operasional strategi. Pada tahap ini, formulasi strategi menjadi sangat detail, dan dapat diturunkan menjadi beberapa hierarki pelaksanaan, diantaranya: (1) hierarki waktu, (2) hierarki visi dan misi, (3) hierarki substrategi, dan (4) hierarki program. Hierarki yang paling umum digunakan adalah hierarki waktu, yang mana di Indonesia kita kenal sebagai jangka panjang (20 tahun), jangka menengah ( 5 tahun), dan jangka pendek atau tahunan (1 tahun). Seluruh proses penyusunan strategi ini kemudian menghasilkan produk akhir berupa "master plan" dengan substansi yang sangat detail. Oleh karena itu, perencanaan strategis seringkali diasosiasikan dengan fungsi "kontrol", karena panduan operasionalnya yang spesifik dan mengikat. Kelima, tahap terakhir dalam perencanaan strategis adalah penyusunan jadwal, yang menyebabkan proses perencanaan strategis selalu dimulai dan diakhiri pada waktu yang sama tiap tahunnya, secara berkala.

Pada kenyataannya, saat ini metode perencanaan strategis sudah jarang atau bahkan tidak pernah lagi digunakan dalam perencanaan di sektor privat (sumber: www.hbr.com). Perencanaan strategis dianggap tidak mampu menghasilkan strategi baru, tapi hanya menganalisis dan mengelaborasi strategi yang sudah ada. Hal ini disebabkan oleh pembentukan strategi yang pada hakikatnya tidak bisa diformalisasikan, karena seperti ide, strategi terbentuk secara tiba- 
tiba, melalui sebuah proses yang disebut "black box of strategy making". ${ }^{1}$ Selain itu, perencanaan strategis membutuhkan dan diwajibkan untuk mengacu kepada hard data, atau data yang sudah dielaborasi menjadi data terukur dan terstruktur, yang notabene membutuhkan waktu lama untuk dibentuk. Perencanaan yang baik seharusnya bersifat responsif dan adaptif terhadap perubahan dan kondisi yang ada di lapangan, sedangkan proses formalisasi yang merupakan identitas dari perencanaan strategis itu sendiri memakan waktu yang lama.

Namun demikian, tidak selamanya perencanaan strategis merupakan sistem perencanaan yang negatif. Setidaknya, terdapat beberapa manfaat dari sifat perencanaan strategis yang formal dan terstruktur. Pertama, sifatnya yang formal memaksa rencana yang dihasilkan harus akuntabel dan dapat dipertanggungjawabkan. Kedua, karena perencanaan strategis pada dasarnya dibuat oleh sistem, pimpinan organisasi atau manajer relative tidak bisa bertindak otoriter untuk mengintervensi rencana yang ada atau rencana yang diamanatkan kepadanya oleh organisasi. Ketiga, dokumen rencana yang elaboratif membuat pelaksanaannya mudah dikendalikan dan relatif mudah disesuaikan dengan instruksi, sehingga tingkat penyimpangan dapat diminimalisasi.

Apabila kita mengacu pada peraturan perundangan yang ada, praktik perencanaan pembangunan di Indonesia diatur melalui Undang-Undang Nomor 25 Tahun 2004 tentang Sistem Perencanaan Pembangunan Nasional (SPPN) beserta segenap peraturan perundangan turunannya. Dokumen perencanaan pembangunan di Indonesia dapat dikelompokkan menjadi 3 (tiga) jenis dokumen berdasarkan hierarki waktu, yaitu: (1) rencana jangka panjang yang tertuang dalam Rencana Pembangunan Jangka Panjang (RPJP) Nasional dan RPJP Daerah; (2) rencana jangka menengah yang tertuang dalam Rencana Pembangunan Jangka Menengah Nasional (RPJMN), Rencana Pembangunan Jangka Menengah Daerah (RPJMD), Rencana Strategis Kementerian/Lembaga (Renstra-K/L), dan Rencana Strategis Satuan Kerja Perangkat Daerah (Renstra-SKPD); dan (3) rencana jangka pendek (tahunan) yang tertuang dalam Rencana Kerja Pemerintah (RKP), Rencana Kerja Pemerintah Daerah (RKPD), Rencana Kerja Kementerian/Lembaga (Renja-K/L), dan Rencana Kerja Satuan Kerja Perangkat Daerah (RenjaSKPD). Dalam hal ini, rencana strategis dalam konteks perencanaan pembangunan di Indonesia didefinisikan sebagai rencana jangka menengah ( 5 tahun).

Tahapan perencanaan pembangunan nasional diatur dalam UU no. 25 tahun 2004 pasal 8-30, yang secara umum terdiri dari: (1) penyusunan rencana, (2) penetapan rencana, (3) pengendalian pelaksanaan rencana, dan (4) evaluasi pelaksanaan rencana. Penyusunan rencana dimulai dengan menyiapkan Rancangan Awal dari RPJPN/RPJMN/RKP. Selanjutnya, Kementerian/Lembaga menyiapkan Renstra-K/L atau Renja-K/L, yang kemudian menjadi acuan dalam menyusun Rancangan RPJPN/RPJMN/RKP. Rancangan tersebut kemudian dibahas dalam Musrenbang Nasional, dan hasilnya akan menjadi pedoman dalam penyusunan Rancangan Akhir RPJPN/RPJMN/RKP oleh Menteri PPN/Bappenas. Proses yang sama juga dilakukan dalam penyusunan rencana strategis daerah, dengan peran Menteri PPN/Bappenas diisi oleh Kepala Bappeda, dan peran Kementerian/Lembaga diisi oleh Kepala SKPD. Rancangan akhir RPJPN/ RPJMN/RKP yang sudah disepakati kemudian ditetapkan melalui peraturan perundangan.

Berdasarkan tahapan perencanaan tersebut, dapat terlihat bahwa rencana strategis di Indonesia secara umum dibagi berdasarkan hierarki waktu (jangka panjang, menengah, tahunan) dan hierarki struktur pemerintahan (pemerintah pusat dan pemerintah daerah). Berbagai rencana strategis ini saling terkait, dimana setiap dokumen rencana harus berpedoman kepada dokumen dengan struktur hierarki diatasnya, dengan RPJPN sebagai rencana induk baik dari segi waktu maupun struktur pemerintahan. Hal ini menegaskan sifat perencanaan strategis yang formal dan mengikat, dimana tujuan dari setiap dokumen perencanaan merupakan turunan dari dokumen yang sudah ada sebelumnya, dan perubahan hanya dapat dicapai melalui amandemen dari peraturan perundangan yang mengesahkannya.

Dalam perkembangan praktik perencanaan dan manajemen pembangunan di Indonesia, sampai saat ini menurut penulis ditengarai masih terdapat beberapa permasalahan yang menghambat dan menjadi kendala terwujudnya proses perencanaan strategis yang berkualitas. Dengan sendirinya, kualitas proses perencanaan strategis tersebut tentunya akan mempengaruhi pencapaian tujuan penyusunan rencana strategis, yaitu sebagai salah satu alat (tool) perencanaan yang pada akhirnya dimaksudkan untuk mencapai tujuan pembangunan itu 
sendiri. Melalui makalah ini, penulis bermaksud mengulas beberapa permasalahan yang menurut penulis berpotensi menurunkan kualitas perencanaan strategis sektor publik di Indonesia.

\section{Analisis dan Pembahasan}

Secara umum setidaknya terdapat 7 (tujuh) permasalahan dalam penyusunan rencana strategis sektor publik di Indonesia. Secara garis besar, permasalahan-permasalahan tersebut dijelaskan dalam uraian di bawah ini.

\section{Perencanaan strategis sebagai sebuah proses legal-formal.}

Salah satu karakteristik dari perencanaan strategis di sektor publik adalah kenyataan bahwa proses perencanaan strategis tersebut diselenggarakan sebagai sebuah proses legalformal. Beberapa hal yang mengindikasikan hal tersebut adalah sebagai berikut: (1) proses penyusunan rencana strategis dipandu oleh pedoman yang ditetapkan melalui peraturan perundangan tertentu, dimana metode, jadwal penyusunan dan substansi dokumen (termasuk daftar isi) telah ditetapkan; (2) dokumen rencana strategis yang telah selesai disusun ditetapkan melalui peraturan perundangan yang akan secara langsung mengikat pelaksanaan rencana strategis tersebut, baik dari sisi program maupun anggaran; dan (3) adanya kewajiban review (revisi) dokumen rencana strategis setelah 2-3 tahun pelaksanaan, yang juga kemudian ditetapkan melalui peraturan perundangan.

Di satu sisi, legalisasi dan formalisasi proses perencanaan dan dokumen rencana strategis memberikan manfaat dalam bentuk stabilitas proses dan produk perencanaan. Berkat legalisasi dan formalisasi, dapat dipastikan bahwa produk perencanaan (atau rencana itu sendiri) akan dilaksanakan dan dengan mengacu pada mekanisme yang telah diatur. Dengan demikian, kemungkinan adanya penyimpangan (deviasi) dapat ditekan seminimum mungkin. Disamping itu, sesuai karakteristik sektor publik yang dalam penyelenggaraannya selalu harus memenuhi akuntabilitas, maka adanya legalisasi dan formalisasi tersebut bermanfaat untuk mengukur sejauh mana proses perencanaan strategis maupun pelaksanaannya telah dilakukan secara akuntabel.

Namun demikian, karakteristik legal-formal tersebut juga memberikan kesulitan tersendiri dalam proses perencanaan strategis. Yang pertama, yaitu bentuk rencana strategis yang relatif rigid (kaku), sehingga pelaksanaannya menjadi kurang fleksibel. Untuk melakukan perubahan terhadap rencana strategis, dibutuhkan proses pembahasan substansi dan penetapan peraturan perundangan baru dengan proses yang mekanismenya telah ditentukan dan memakan waktu relatif panjang. Seperti diulas dalam buku Good Strategy/Bad Strategy (Rummelt, 2011), bahwa perubahan dalam lingkungan strategis suatu organisasi pada kenyataannya tidak terjadi dalam bentuk dan pola yang teratur sehingga proses untuk melakukan adaptasi serta penyesuaian strategi pun pada hakikatnya tidak bisa distrukturkan.

Disamping itu, banyaknya peraturan perundangan yang diacu dalam penyusunan rencana strategis juga memberikan tantangan tersendiri, baik berupa dokumen perencanaan yang tingkatannya lebih tinggi maupun Norma, Standar, Prosedur, dan Kriteria (NSPK) terkait perencanaan serta NSPK sektoral. Hal ini mengakibatkan proses penyusunan rencana strategis secara substantif harus disusun dengan mempertimbangkan banyak sudut pandang dan kepentingan, yang tidak menutup kemungkinan dapat saling bertolak belakang atau bersifat tidak koheren satu sama lain.

\section{Kesalahan dalam melakukan penetapan sasaran.}

Karena status legal-formal dari proses penyusunan rencana strategis maupun dokumen rencana strategis itu sendiri, penetapan sasaran pada rencana strategis juga bersifat cukup rigid. Hal ini disebabkan oleh rencana strategis maupun dokumen rencana strategis yang secara normatif harus mengacu pada dokumen perencanaan yang hierarkinya lebih tinggi, baik dari segi waktu maupun struktur pemerintahan. Kesalahan dalam penetapan sasaran bisa menyebabkan tidak sinkronnya sasaran antar dokumen perencanaan.

Kesalahan di atas bisa terjadi karena beberapa hal. Pertama, karena para penyusun rencana strategis kurang memahami bahan/dokumen perencanaan atau peraturan perundangan yang seharusnya dijadikan acuan. Kedua, karena ketidaksinkronan planning horizon ${ }^{2}$ antara 
dokumen-dokumen perencanaan yang berbeda. Hal ini mengakibatkan terbuka kemungkinan terjadinya kesalahan penyusunan sasaran pada dokumen rencana strategis yang tingkatnya lebih rendah, contohnya RPJMD yang tidak sinkron dengan RPJMN, Renstra K/L yang tidak sesuai dengan RPJMN, dan lain sebagainya.

Apabila kesalahan-kesalahan tersebut tidak diperbaiki, sebagai akibatnya penyusunan program dan anggaran yang disusun berdasarkan sasaran-sasaran pada dokumen perencanaan pembangunan tertentu, dapat menjadi tidak sinkron dengan tujuan atau sasaran pembangunan nasional secara keseluruhan. Mekanisme revisi dokumen rencana strategis yang umumnya cukup panjang dan memakan waktu juga mengakibatkan kesalahan penetapan sasaran tersebut tidak dapat segera diperbaiki dengan cepat.

Disamping menyebabkan tidak sinkronnya program dan anggaran, kesalahan penetapan sasaran juga dapat mengakibatkan kesulitan dalam pengukuran kinerja secara agregat dikarenakan kemungkinan indikator kinerja yang tidak sama. Hal ini membuat pelaksanaan dokumen-dokumen rencana strategis yang berbeda namun terkait menjadi sulit untuk diukur kinerjanya (lintas K/L, lintas pusat-daerah, atau lintas daerah).

Padakenyataannya, seringkali para perencanadi lingkungan instansipemerintahcenderung untuk berupaya mempertahankan dokumen perencanaan yang secara substantif mengandung kesalahan dikarenakan begitu kuatnya keabsahan legal-formal dari suatu dokumen rencana. Kecenderungan perilaku tersebut bisa juga terjadi dikarenakan para perencana menyadari bahwa proses untuk merevisi dokumen rencana membutuhkan upaya dan waktu yang panjang sehingga keputusan untuk melakukan revisi seringkali tidak praktis. Sebagai contoh, revisi RPJMD yang sedang berjalan untuk menyesuaikan dengan RPJMN yang baru bisa membutuhkan waktu cukup lama sehingga waktu efektif yang tersisa untuk melaksanakan RPJMD yang baru (hasil revisi) menjadi terlalu sempit atau bahkan bisa jadi tidak ada pengaruhnya sama sekali.

\section{Kesulitan dalam melakukan prediksi terhadap masa depan}

Sebagai sebuah metode perencanaan, proses perencanaan strategis membutuhkan adanya prediksi terhadap masa depan yang menyangkut berbagai faktor yang mempengaruhi pelaksanaan rencana strategis, diantaranya: besaran volume target tahunan; ketersediaan anggaran; risiko-risiko yang berpotensi menghambat pelaksanaan rencana; dan lain sebagainya. Hal ini terutama disebabkan oleh planning horizon yang cukup panjang dalam perencanaan strategis sehingga mengakibatkan perlunya dilakukan asumsi dan estimasi terhadap faktorfaktor penentu keberhasilan pelaksanaan rencana.

Namun demikian, kemampuan untuk memperkirakan masa depan atau forecasting sudah tentu tidaklah mudah khususnya dalam suatu lingkungan strategis yang bersifat dinamis dan cepat berubah. Kecenderungan yang ada sampai dengan saat ini, menurut pengamatan penulis, adalah secara umum praktik forecasting dalam sektor publik masih didominasi oleh pemikiran yang linier (linear thinking) serta adanya kecenderungan untuk menggunakan asumsi-asumsi yang memperkirakan gambaran masa depan berdasarkan apa yang terjadi di masa lalu. Sudah tentu, hal ini memberikan keterbatasan dalam memperkirakan masa depan sehingga kemungkinan banyak terjadi kesalahan dalam forecasting. Dampaknya terhadap perencanaan adalah kenyataan bahwa banyak asumsi yang tidak menjadi kenyataan sehingga rencana menjadi tidak relevan dengan situasi dan kondisi aktual.

Salah satu permasalahan yang sering terjadi dalam proses perencanaan strategis sampai dengan saat ini adalah kecenderungan untuk bersikap terlalu optimis (over optimistic) terhadap kemungkinan ketersediaan sumber daya di masa depan. Pada kenyataannya fenomena backlog anggaran menjadi hal yang umum terjadi di banyak sektor yang pada gilirannya menyulitkan pencapaian sasaran.

Oleh karena itu, ke depan, diperlukan adanya kemampuan untuk dapat melakukan forecasting dengan lebih akurat menggunakan metode-metode yang lebih mutakhir daripada yang dilakukan pada saat ini. Demikian pula, kesadaran untuk melakukan risk management dalam penyusunan rencana strategis juga perlu ditingkatkan sehingga upaya-upaya untuk mengantisipasi risiko kegagalan juga dapat dimasukkan sebagai bagian dari rencana strategis itu sendiri.

\section{Proses perencanaan strategis yang kurang partisipatif}

Dalam literatur manajemen, suatu rencana strategis secara substantif pada dasarnya 
memuat visi dan misi organisasi yang mengarahkan jalannya organisasi ke depan. Sudah tentu seharusnya rencana strategis perlu untuk dipahami dan dihayati oleh segenap anggota organisasi dari level tertinggi hingga level terendah. Pemahaman dan penghayatan oleh setiap anggota organisasi tersebut baik secara langsung maupun tidak langsung akan mempengaruhi pelaksanaan setiap kegiatan organisasi yang pada gilirannya diharapkan akan berkontribusi terhadap pencapaian visi dan misi organisasi. Seperti diulas dalam The Fifth Discipline (Senge, 1990) tentang pentingnya "shared vision" yang menciptakan identitas yang sama serta memfokuskan energi dari seluruh individu anggota organisasi kepada tujuan organisasi.

Apabila kita perhatikan pada organisasi sektor publik, atau instansi-instansi pemerintah, kenyataan yang ada menunjukkan bahwa umumnya struktur organisasi instansi pemerintah cenderung besar dan mempunyai jumlah pegawai yang banyak. Hal ini mengakibatkan selama ini proses penyusunan rencana strategis serta pemahaman akan substansinya umumnya cenderung didominasi oleh para pimpinan di tingkat tertinggi dan/atau para pejabat/pegawai pada unit-unit perencanaan.

Di satu sisi, hal tersebut di atas pada hakikatnya merupakan konsekuensi dari pembagian tugas dan spesialisasi fungsi dalam organisasi (division of labor) sesuai dengan tugas dan fungsi birokrasi. Namun demikian, rencana strategis sebagai sebuah dokumen perencanaan yang mengarahkan gerak organisasi dalam jangka panjang selayaknya dipahami dengan baik oleh setiap pejabat/pegawai pada setiap tingkat dan bidang penugasan. Faktanya, kuesioner pengukuran Reformasi Birokrasi (RB) yang diedarkan kepada para pegawai, salah satunya menanyakan mengenai sejauh mana pemahaman dan keterlibatan pegawai dalam penyusunan rencana strategis. Hal ini mempertegas perlunya pemahaman akan rencana strategis sampai dengan tingkat terendah.

Tentunya, pemahaman yang baik tentang rencana strategis akan dapat mengarahkan segenap keputusan dan tindakan yang diambil oleh para pejabat/pegawai, sehingga dipastikan keseluruhan gerak organisasi akan memberikan kontribusi positif secara koheren pada perwujudan visi dan kesuksesan misi organisasi. Demikian pula, hal tersebut dapat menghindarkan adanya keputusan dan tindakan pada tingkat operasional yang bertentangan dengan rencana strategis atau secara langsung tidak mendukung terhadap pencapaian visi dan kesuksesan misi organisasi.

\section{Kesulitan dalam menciptakan struktur kinerja yang berjenjang secara sistematis}

Rencana strategis instansi pemerintah pada dasarnya merupakan integrasi dari struktur perencanaan, struktur anggaran, struktur organisasi dan struktur kinerja. Dengan demikian, dalam dokumen rencana strategis selain terdapat rencana kegiatan juga harus dilengkapi dengan indikator kinerja yang berjenjang yaitu: (1) Indikator Kinerja Kegiatan (IKK); (2) Indikator Kinerja Program (IKP); dan (3) Indikator Kinerja Sasaran Strategis (IKSS), seperti tertuang dalam Peraturan Menteri PPN/Ka. Bappenas No. 5 Tahun 2014 tentang Pedoman Penyusunan dan Penelaahan Renstra K/L Tahun 2015-2019.

Secara garis besar, hubungan antara ketiga indikator di atas bersifat analog dengan struktur organisasi dimana IKK menggambarkan keluaran langsung kegiatan (output) yang merupakan kinerja Unit Organisasi Eselon II, IKP menggambarkan manfaat program (outcome) yang merupakan kinerja Unit Organisasi Eselon I; adapun IKSS menggambarkan dampak dari keseluruhan program (impact) yang merupakan kinerja K/L. Sudah tentu, dengan gambaran semacam itu maka sebagai konsekuensinya maka indikator kinerja harus disusun secara berjenjang di setiap tingkatan organisasi yang menggambarkan kinerja di masing-masing tingkatan sekaligus menggambarkan hubungan sebab dan akibat diantara indikator kinerja pada tingkat yang berbeda tersebut secara hierarkis.

Seringkali dijumpai adanya struktur kinerja yang tidak tepat dan kurang sistematis, misalnya: penggunaan indikator kinerja yang kurang tepat; penggunaan satuan indikator yang kurang tepat; penggunaan indikator yang pengukurannya sulit atau datanya tidak tersedia di lapangan; hubungan sebab-akibat yang lemah antara indikator kinerja dan sasaran yang dituju; indikator sangat jauh berada di luar rentang kendali organisasi; dan lain sebagainya. Secara umum, kesalahan-kesalahan tersebut banyak terjadi pada penyusunan IKP dan IKSS. Adapun penyusunan IKK pada umumnya lebih mudah dilakukan karena terkait dengan keluaran langsung kegiatan (output) sehingga adanya kesalahan relatif lebih jarang terjadi.

Kesalahan dalam penyusunan indikator kinerja sudah tentu akan memberikan dampak 
negatif yang serius terhadap kualitas rencana strategis, khususnya dalam hal pengukuran kinerja dari rencana strategis dimaksud. Tanpa struktur kinerja yang baik dan berjenjang secara sistematis, maka kinerja organisasi akan sulit diukur. Pada akhirnya, kinerja yang sulit diukur akan mengurangi akuntabilitas dari instansi pemerintah.

Ke depan, sudah tentu setiap dokumen rencana harus dilengkapi dengan serangkaian indikator yang tepat yang dapat memberikan umpan balik secara optimal. Jangan sampai dokumen rencana selesai disusun namun kemudian secara tidak sadar menyimpan masalah berupa indikator-indikator yang menimbulkan kesulitan di kemudian hari.

\section{Kesulitan dalam pengukuran dan pengelolaan kinerja manfaat dan dampak}

Masih terkait dengan perlunya struktur kinerja yang baik sebagaimana dibahas dalam poin di atas, permasalahan seringkali terjadi dalam pengukuran kinerja dimana khususnya untuk IKP dan IKSS. Kedua indikator tersebut seringkali sulit untuk diukur kinerjanya secara terusmenerus seperti halnya IKK. Tentunya hal ini merupakan permasalahan yang cukup mengganggu dalam rangka pelaporan kinerja khususnya pada instansi-instansi pemerintah.

Terdapat beberapa hal yang menyebabkan pengukuran kinerja IKP dan IKSS seringkali sulit untuk dilakukan. Pertama, kesalahan dalam penyusunan IKP dan IKSS yang menyebabkan kinerjanya sulit diukur. Kedua, indikatornya memerlukan data yang harus diukur dan dipantau secara khusus serta berbeda dengan pemantauan terhadap IKK yang merupakan hasil keluaran langsung proyek. Ketiga, kinerja IKP dan IKSS seringkali mendapatkan prioritas yang lebih rendah untuk dipantau dikarenakan tingkat urgensi pelaporannya yang lebih rendah daripada pelaporan kinerja IKK yang umumnya diperlukan dalam mengadministrasikan pertanggungjawaban pelaksanaan proyek.

Tanpa adanya pengukuran kinerja yang memadai khususnya menyangkut IKP dan IKSS maka kinerja instansi pemerintah menjadi sulit untuk diukur dalam kerangka program management. Pada umumnya, perhatian terbesar terhadap kinerja organisasi lebih sering diarahkan pada kinerja proyek-proyek yang diukur melalui IKK, khususnya pada keluarankeluaran proyek yang dimasukkan sebagai kategori proyek strategis (output utama).

Dalam kondisi demikian, penyelenggaraan program-program akan menjadi lebih sulit untuk mencapai IKP dan IKSS dikarenakan mekanisme feedback yang kurang memadai. Lebih jauh, hal tersebut juga akan berakibat pada kesulitan untuk mengetahui sejauh mana pencapain visi dan misi organisasi, yang mana hakikatnya merupakan akumulasi dari pencapaian keseluruhan proyek yang dilaksanakan.

Pada akhirnya, hal yang terpenting dalam suatu organisasi sektor publik, adalah sejauh mana seluruh program dan kegiatan dapat menghasilkan manfaat dan dampak yang diharapkan, yang mana terkait erat dengan kesejahteraan masyarakat. Perlu dicatat bahwa meskipun output proyek mutlak diperlukan untuk menghasilkan manfaat (outcome) dan dampak (impact, namun dalam praktiknya, output delivery tidak menjamin terealisasikannya manfaat dan dampak dikarenakan adanya faktor-faktor eksternal yang berada diluar kendali organisasi. Oleh karena itu, diperlukan upaya-upaya khusus untuk memastikan output dari proyek-proyek yang dilaksanakan dapat semaksimal mungkin menghasilkan manfaat dan dampak. Secara teoritis, hal ini sebenarnya merupakan bidang tersendiri yang disebut benefit realization management yang mana secara umum masih belum banyak dipraktikkan oleh organisasi sektor publik di Indonesia.

\section{Kesulitan dalam melakukan prioritisasi secara optimal dalam penyusunan program dan anggaran.}

Keberhasilan pelaksanaan rencana strategis dalam rangka mencapai visi dan misi sepenuhnya tergantung pada hasil pelaksanaan proyek-proyek yang dilaksanakan secara kontinyu sepanjang planning horizon dari rencana strategis tersebut. Proyek-proyek yang dilaksanakan akan menghasilkan kinerja yang diukur melalui pencapaian IKK, yang pada gilirannya akan berkontribusi pada pencapaian IKP dan IKSS serta bermuara pada keberhasilan pencapaian visi dan misi organisasi.

Dalam konteks program management, ${ }^{3}$ hakikat proses perencanaan strategis adalah untuk memilih kombinasi atau portofolio proyek-proyek yang tepat untuk dilaksanakan dalam

3. Program management atau manajemen program dapat didefinisikan secara sederhana sebagai proses untuk mengelola sekumpulan proyekproyek yang saling berkaitan dalam rangka mencapai visi dan misi organisasi 
rangka mencapai visi dan misi organisasi. Dalam istilah pakar manajemen Peter F. Drucker, hal ini digambarkan dengan istilah "doing the right project" dan pada hakikatnya sangat berbeda dengan kinerja project management yang menitikberatkan pada keberhasilan pelaksanaan proyek untuk menghasilkan keluaran proyek (output) yang digambarkan dengan istilah "doing the project right".

Seringkali terjadi, organisasi memilih proyek yang tidak tepat atau tidak selaras dengan tujuan-tujuan strategisnya (visi dan misi organisasi). Walaupun proyek tersebut bisa dilaksanakan dengan baik sesuai kaidah project management - tepat waktu, tepat mutu dan tepat biaya - tentunya kontribusinya tidak akan optimal terhadap pelaksanaan rencana strategis atau kinerja program management.

Salah satu permasalahan dalam penyusunan program dan kegiatan atau seleksi proyek adalah karena proyek-proyek yang dipilih untuk dilaksanakan seringkali bersifat "amanat" (compulsory), yaitu merupakan kewajiban organisasi yang berasal dari: dokumen perencanaan yang lebih tinggi, keputusan politik, dan lain-lain. Hal ini menyebabkan kurangnya kesempatan bagi para perencana untuk melakukan analisis atau simulasi untuk menghasilkan kombinasi proyek-proyek yang terbaik sesuai dengan kaidah program management.

Oleh karena itu, sudah tentu proses penyusunan program dan anggaran perlu dilaksanakan secara seksama dalam rangka memberikan hasil terbaik atau leverage yang tertinggi dilihat dari sudut pandang pencapaian visi dan misi. Kendala utama yang dihadapi tentunya adalah keterbatasan anggaran yang mana membutuhkan kecermatan dalam melakukan prioritisasi atau trade-off apabila memang terdapat proyek yang harus dikorbankan demi tujuan yang lebih besar. Untuk itu, diperlukan serangkaian tools atau kriteria yang komprehensif untuk menyusun skenario terbaik pencapaian tujuan organisasi melalui kombinasi program dan anggaran tertentu.

\section{Penutup}

Dari penjelasan di atas dapat disimpulkan bahwa permasalahan dalam perencanaan strategis di sektor publik di Indonesia dapat dibagi ke dalam 3 (tiga) kategori: (1) Permasalahan intrinsik yang memang tidak dapat dihindarkan, (2) Permasalahan yang bisa dihindarkan dengan memperbaiki mekanisme yang ada, dan (3) Permasalahan yang bisa dihindarkan dengan membuat mekanisme baru.

Kategori pertama adalah permasalahan yang bersifat intrinsik dan merupakan karakteristik dari perencanaan strategis itu sendiri, contohnya adalah sifat perencanaan strategis yang legalformal. Pelaksanaan perencanaan yang rigid dan keterikatannya dengan peraturan perundangan merupakan trade off atau harga yang harus dibayarkan untuk mencapai stabilitas proses dan produk perencanaan, perencanaan yang akuntabel, dan perencanaan yang minim deviasi, yang merupakan benefit dari perencanaan yang bersifat legal-formal.

Sedangkan, kategori kedua adalah permasalahan dalam perencanaan strategis yang masih bisa dihindarkan dengan menerapkan mekanisme yang lebih baik, yaitu: mengadakan pemilihan kepala daerah serentak guna menyamakan planning horizon; menetapkan indikator dan satuan tunggal untuk pekerjaan yang sama pada dokumen perencanaan yang berbeda untuk memudahkan pengukuran kinerja; membuat sosialisasi rencana strategis kepada pegawai nonbagian perencanaan untuk menyamakan visi dan arah kerja; membuat indikator kinerja yang lebih mudah untuk diukur secara kontinyu khususnya untuk IKP dan IKSS; dan lain sebagainya.

Kategori terakhir adalah permasalahan yang dapat dipecahkan dengan menerapkan mekanisme baru yang berbeda dengan yang ada saat ini. Salah satu contohnya adalah dengan membuat mekanisme forecasting yang lebih baik agar perencanaan yang disusun menjadi relevan dengan kondisi aktual. Contoh lainnya adalah dengan menyusun pedoman untuk melakukan seleksi proyek dalam rangka melaksanakan praktik program management yang baik, dan lain sebagainya.

Pada akhirnya, menurut penulis, sistem perencanaan strategis yang diterapkan di Indonesia ini ditengarai tidak akan berubah secara drastis, karena secara keseluruhan sudah sesuai dengan tuntutan perencanaan sektor publik di Indonesia. Meski begitu, seperti yang disampaikan pada paragraf di atas, masih banyak aspek dari perencanaan strategis ini yang bisa kita tingkatkan. Penulis berharap segenap pihak yang berperan dalam sistem perencanaan strategis di Indonesia, baik yang memiliki tugas dan funsgi perencanaan ataupun tidak, berinisiatif untuk mengevaluasi kinerja masing-masing dan turut aktif berpartisipasi dalam 
meningkatkan aspek-aspek dari perencanan strategis tersebut di atas. Dengan upaya-upaya tersebut, diharapkan pelaksanaan perencanaan strategis di sektor publik di Indonesia menjadi lebih efektif dan mampu mengakomodasi terobosan-terobosan baru, seperti yang diharapkan oleh Bapak Presiden Indonesia. 


\section{Daftar Pustaka}

ChangeCom. 2012. "Book of the Week: Strategy Safari". https://changecom.wordpress. com/2012/12/27/strategy-safari/, diakses pada 28 April 2017

Mintzberg, Henry. 1998. Strategy Safari. New York: The Free Press

Mintzberg, Henry. 1994. "The Fall and Rise of Strategic Planning" dalam Harvard Business Review edisi Januari-Februari 1994. Boston: Harvard Business Publishing

Pelling, Nick. 2004. Mintzberg's Ten School. Kingston: Kingston Business School

Peraturan Menteri PPN/Ka. Bappenas No. 5 Tahun 2014 tentang Pedoman Penyusunan dan Penelaahan Renstra K/L Tahun 2015-2019

R., Mustopadidjaya A. 2012. Bappenas dalam Sejarah Perencanaan Pembangunan Indonesia, 1945-2025. LP3ES: Jakarta

Rumelt, Richard P. 2011. Good Strategy/Bad Strategy. London: Profile Books

Senge, Peter. 1990. The Fifth Discipline: The art and practice of the learning organization. New York: Doubleday

Stefanie, Christie. 2017. "Buka Musrenbang, Jokowi Keluhkan Kondisi Pembangunan". http:// www.cnnindonesia.com/ekonomi/20170426113203-78-210190/buka-musrenbangjokowi-keluhkan-koordinasi-pembangunan/, diakses pada 1 Mei 2017 